\title{
Region as a factor changes on a Global Scale
}

\author{
Miroslaw Przygoda \\ University of Warsaw, Faculty of Management, Warsaw, Poland, \\ miroslawprzygoda@wp.pl
}

\begin{abstract}
The term "region" originating from a Latin word: regio, has two meanings in itself in terms of etymology - first, it is a movement in a fixed direction, and the second one denotes space. Combination of both results in: "movement in a fixed direction, which defines space". The meaning generally relating to the area, has over time dominated the vernacular understanding of the whole word. Currently, the concept is in principle used to exclusively describe a given territory. However, nowadays, the return to the primeval meaning of the word seems to be more and more justified as well as there should be more attention paid to changes in the specific direction which result from transformations taking place within regions. For a long time, regions were most of all and exclusively treated as the largest units of administrative division of individual countries. The most important subject within the pursued regional policy was a fast and efficient integration of areas indicating development inequalities. The particular attention was paid in this scope to equalize cultural distinctions and the level of their economic growth. Despite the multi-billion expenditure, the established goals have not been fully achieved. Progressing globalization have allowed local authorities to go beyond the narrow framework of inland structures. Currently, the regional authorities have become an essential factor and entity of policies in transnational dimension. In many cases, it has become the cause to radicalize social attitudes. In extreme cases, increase in importance of regions has resulted in local disputes of economic and political nature, and in some situations it has even led to military conflicts. It is to be assumed that we are witnesses to a broader phenomenon which may disturb the fragile balance created on international arena still in the second half of the 20th century. Attempts of specific regions emphasizing their autonomy to achieve greater or even total independence, are currently taking place in nearly every corner of the world. In turn, the lack of flexibility of national authorities in the face of demands placed by local communities creates a dangerous situation of an outbreak of new conflicts on a larger than local scale. With interest in inciting unrest and with active engagement of some world powers, it may lead to geopolitical changes on a great scale. Regions, as a simple tool remaining in specific hands, may in this manner become a factor of serious and dangerous transformations in an international dimension.
\end{abstract}

Keywords: Autonomy, Change, Factor, Globalization, Region.

\section{Introduction}

In recent years the dramatic increase in the importance of regions has been observed. This phenomenon has its place in many fields. However, it has become the most visible in extremely significant areas of life such as economy and politics. Regions by the definition constitute most frequently a component of some larger territory - mostly a country. Nevertheless, their impact has been for a longer period of time exceeding with its reach borders of one specific country. The "region" concept originating from a Latin word: regio, has two meanings in itself in terms of etymology - first, it is a movement in fixed direction, and the second one denotes space. Combination of both results in: "movement in fixed direction, which defines space". The meaning generally relating to the area, has over time dominated the vernacular understanding of the whole word. Currently, the concept is in principle used to exclusively describe a given territory. However, nowadays, the return to the primeval meaning of the word seems to be more and more justified as well as there should be more attention paid to the changes in the specific direction which result from transformations taking place within regions. As a rule, regions are treated most of all as the largest units of administrative division of individual countries. The progressing globalisation has allowed the described areas to go beyond the narrow framework of inland structures. They have become an essential entity of economic and social activity in the transnational dimension. A large role in this process is played by both radical social attitudes and actions of local authorities planned in perspective of many years. 


\section{Factors Affecting the Increase in the Importance of Regions}

The noticeable increase in the role of regions on the international arena can be noticed since the second decade of the 20th century. The changes taking place in the world as the outcome of the World War I had influence on that condition. At the moment of finishing armed struggles in 1919, transformations on a then-unprecedented scale occurred. They were of extremely diverse nature. They were the effect of tumultuous revolutions on socio-political basis or also of planned transformations on the basis of international agreements entered into. Economic order different to one yet applicable was being formed, new borders were traced out, large superpowers were collapsing, state units were being created on the basis of integrated regions belonging until recently to parties fighting each other. New players, who were to affect future events in the global scale, appeared on the stage. End of World War I definitively abolished the order established yet in 19th century. Another revolutionary moment, which changed configuration and significance of individual regions, was World War II. This conflict re-developed new administrative, territorial, political and economic structures. However, they had wider range and significance and they were carried out in much larger scale comparing to ones of the previous turbulences. In Europe, North America, South America and Australia shortly after 1945, there had been introduced the new political and economic order which survived only with some minor changes almost until the last decade of the previous century. Whereas, exceptionally sudden and dynamic transformations took place after World War II in Asia, Africa and this part of America which is to be colloquially known as Central. Their particular escalation falls on 1950's and 1960's of the previous century and the end of the process of changes relates to the half of the 1970's. Mainly they were of the character of fighting with colonialism and of social revolutions. The important events: peaceful reunification of Germany, disintegration of the Soviet Union and civil war in Yugoslavia broke the existing status quo in Europe in the beginning of 1990's. Changed in terms of territory or entirely new state units appeared on the world map. It turned out that both independence secured by fighting as well as tracing out of new borders in Europe are still possible. Initially, it seemed that the changes would be of a limited character. But soon pro-independence tendencies of regions and striving for own statehood divided Czechoslovakia into two and were emphasized with increased intensity in Belgium, Spain and the United Kingdom. In these three countries, desire for independence of individual regions adopted a democratic character and took the path of peace. However, what happened in former Yugoslavia and the Soviet Union took the tragic course and resulted in thousands of unnecessary human victims. The dangerous memento for both described incidents were the latest events in the Ukraine. Annexation of Crimea by Russia and war in the Ukraine on the centenary of the outbreak of World War I call up bad associations for the upcoming future. One may suppose that currently we are witnesses of far-reaching changes which have their beginning on the regional level, however their impact will have transnational or even global range. In here one should think of the cause of increase in the importance of regions, starting with the national level to transnational or even global scale. The following is to be included as main reasons for such state:

- $\quad$ the existing industrial and economic infrastructure,

- $\quad$ possession or discovery of rare or valuable resources,

- $\quad$ increase in economic potential of selected areas,

- historical conditions,

- $\quad$ investment attractiveness,

- $\quad$ international co-operation

- $\quad$ crucial location in geographical and strategic sense,

- $\quad$ growing awareness of citizens of a given territory,

- $\quad$ exhaustion of natural resources or their lack in some regions,

- $\quad$ increased international activity of local and self-government authorities,

- $\quad$ targeted actions of foreign institutions and entities on a specific territory,

- $\quad$ looming crisis within a given country or its loss of importance on the international arena,

- treatment of specific regions as a political tool with intention to conduct imperialistic policy by specific countries. The above list does not include all potential causes of increase in the importance of regions to the level in which their impact start to relate to international scale. However, the listing is compliant with the so-called: "causal approach" which divides causes of formation of regions into natural and acquired factors (Przygoda M., 2013, p. 36). Analysing the list one can observe that the following acquired factors have a substantial preponderance:

- $\quad$ economic (industrial or agricultural)

- $\quad$ administrative (political),

- $\quad$ ethnic (cultural and social).

Whereas, the natural factors, consisting of climatic, zoogeographic and physico-geographical elements, lost in the $21 \mathrm{st}$ century much of their original significance.

\section{Consequences of Increase in the Role of Regions}

Change of the scope of impact of regions from the national to transnational and global scale, requires a formation of a new approach to the issue of their classification. Comparisons taking into consideration for example: level of regional GDP, local unemployment rate, amount of employees' remuneration, age structure, education level or scope and financial means for social aid, are being performed since many years for needs of national authorities and also international organizations. In many events institutions such as: the European Union (EU), North American Free Trade Agreement 
(NAFTA), Association of Southeast Asian Nations (ASEAN), World Bank (WB) or European Bank for Reconstruction and Development (EBRD), have created their own record systems or systems for processing of necessary for them data or information. However, in most cases they are of statistical nature. They base largely on records, numerical rankings and comparisons of graphic character which main task is to create a uniform model presenting the current or possibly the forecasted economic situation of given territorial structures. Within the aforementioned organizations, there are also being created financial funds and numerous programs which task it is to most of all achieve the established objectives of economic and social development. In that sense there is the lack of studies which in the foreground displays significance of important territories in relation to their role in international relations and possibilities of affecting the global situation. Such materials are being created but most frequently in a different depiction. They generally relate to problem areas within various countries. Their task is to present solutions aiming at resolving the tense political situation on a given, limited area or also to define manners of aid in the case of natural disasters or catastrophes in humanitarian sense. Therefore the creation of a classification which takes into consideration importance of selected regions, as the factor of changes in the global scale, seems desirable. This type of study will allow to create a new approach model for the issue discussed. It will simultaneously pay attention to the essence and importance of the issue of increased role of regions in the current world.

\section{Classification of Regions According to the Criterion of the Factor of Their Significance and Influence on Changes in the Global Scale.}

The below classification constitutes the attempt to list and compare exemplary regions according to the area of their impact on in the international scale. However one should be aware of the fact that not all separated areas exert such impact. The vast majority has not yet reach the level of impact on the transnational scale or it is not properly conditioned to ever reach such state. These regions which constitute the factor of changes on the global scale are in some sense territories of special importance and exceptional when it comes to the features they possess. However technical progress, in particular in the field of telecommunication and dynamically changing political situation of the entire planet, results in the constant increase of territories due to different reasons essential for the nature of today's world. The presented groups of regions have been arranged according to the list. It takes into consideration the possibilities of their potential influence on events in the global scale. At the beginning of the listing there are the regions which impact is the greatest. On further positions there have been introduced ones which role in the described phenomena is smaller. The presented list has been arranged on the basis of the assumption based on the deductive path of conduct. However, the premises for this activity are not a will to create a firm axiom. It was rather about sketching an elastic model of conduct taking into consideration current and future events. By the use of it, it would be possible to note the most important phenomena ans subsequently to give them a value and range them in relation to the influence on the existing and future global situation.

Classification of regions according to factors: their significance and influence on changes in the global scale.

\subsection{Limited, in Geographical Sense, Areas in Which There is an Open War or Armed, Repeated Clashes Take Place.}

Such situation relates to at least two antagonized countries. It may also relate to units aspiring to become an independent country but are not recognised by a wide international opinion. Examples:

- Conflict of a few decades between India and Pakistan fighting for the border area of Kashmir.

- Confrontation in the Gaza Strip between Israel and forces representing the Palestinian Autonomy.

- Golan Heights - the conflict area included in 1981 in the territory of Israel, for the return of which Syria and Liban fight. For many years at the moment of tension in the Near East, border incidents and exchange of fire between the conflicted parties take place.

Consequences for the situation of the world: In the majority of cases, behind the armed conflicts taking place there are interests of the largest superpowers and economic powers of the world. Acts of war polarize specific political and social forces, placing them on opposite poles. There occur cooling of international relations in the sphere of trade and limitations of all other forms of mutual contact between countries supporting the conflicted parties. A direct intervention into the armed conflict to support one of the fighting parties of a single country or a group of countries may take place. The involvement may be of a direct nature or only limit to the sphere of logistics. Tension on the international arena is increasing. A real threat of a conflict expanding into neighboring countries. Military spending is increasing in the global scale. Less funds are being allocated for consumption, development and in favor of citizens. Taxes are increasing. Anti- 
war activists' demonstrations and numerous social protests are taking place. The described situation results in the biggest threat of destroying the existing world order.

\subsection{Regions in Which There is a Severe Political Conflict and a Threat of Outbreak of Military Clashes.}

In the majority of cases, this issue relates only to two countries. Each of them manifests a desire to create their own zone of influence and aspirations for the role of a force leading in a given area. The examples may be:

- Conflict regarding the archipelago of islands located on the East China Sea, which Japan refers to as Senkaku and China

- Diaoyu. The conflict relates to the Country of the Rising Sun and the Middle Kingdom.

- Kuril Islands located on the Pacific Ocean. The object of contention between Japan and Russia making it impossible to sign the peace treaty officially ending the World War II between these countries,

- The already ended conflict of many years related to Beagle Channel between Argentina and Chile. Beagle Channel is a narrow strait approx. 370 kilometres wide, between the islands which belong to Tierra del Fuego archipelago. It is located at the southern end of the South America's continent.

- Quemoy and Matsu Islands located in the Taiwan Strait constitute the conflict territory of Taiwan and the People's Republic of China since the end of the civil war in 1949 (Kerr G.H., 1992, p. 430)

Consequences for the situation of the world: The after-effect of the political conflict relating to head authority over a given area are dangerous demonstrations of military force of both conflicted parties. They may even transform into short military skirmishes. The reason for the conflict is most frequently a discovery in the described areas or, as in the event of the mentioned cases - on waters surrounding them, valuable natural resources such as petroleum and natural gas. For some time, trade between adversaries is limited or entirely discontinued and decline in mutual relations take place. As in the case of the second conflict of Taiwan, there may even exist a threat of outbreak of military actions on a global scale. Other countries, recognized international organizations and authorities engage in mediations aiming at resolution of the existing conflict.

\subsection{Regions Located Within One or a Few Neighboring Countries Which with Insurgent Activities Attempt to Create Their Own Statehood Based on National Criterion.}

Tribal or national community which pushes societies living in the specific area and belonging to the same ethnic group into armed struggle for liberation and independence, is decisive. The examples here are:

-Secession of Katanga in 1960 - 1963. The attempt of armed separation of this province from the Democratic Republic of the Congo.

- Aims of ETA group (to form independent Basque Country). Armed activities of this organization took place in Spain and to a lesser extent and with the use of peaceful methods in France.

- Fight of Kurdish Nation for formation of its own country. Military actions of Kurds aiming at independence are the activity mainly on the territory of Iraq and Turkey but also the areas of Syria and Iran (Wójcik L., 2014, p. 38 - 40).

Consequences for the situation of the world: Derivative of an armed struggle of ethnic groups for formation of their own country is always a military counteraction of a country to which a given region belongs. A country which most frequently, by the use of brutal methods, tries to maintain its territorial integrity is doomed to condemnation of international social opinion and is generally severely sanctioned in terms of economy. There are attempts to resolve the conflict with participation of authorities and international institutions. Mediations and efforts take place in order to create conditions to begin peace talks. Devastation or annihilation of material infrastructure have their place in the entire region in turmoil. Also humanitarian catastrophes, such as famine and diseases, occur frequently. Rapes of civilians and genocide happen repeatedly. Regions which lost their fight for independence become quite frequently problematic areas doomed to constant aid of other countries and specialized organizations. The derivative is an escape of population from areas of the fighting to neighboring countries. It creates a problem of providing safety and living conditions to thousands or refugees.

\subsection{Regions Seized with the Use of Political Solutions and Settlements by Force by Larger Countries from Smaller and Weaker Countries.}

The examples of such conduct:

-Occupation in 1938 by Third Reich of the so-called: "Sudetenland" belonging to Czechoslovakia. 
-Annexation by India with the use of military action of colonial estates belonging to Portugal: Diu, Daman i Goa (socalled Portuguese India), located on the Indian subcontinent. The short-term war for these territories between India and colonial armies of Portugal took place in December 1961.

-Annexation of Crimea to Russia despite protests of the Ukraine and the majority of world's countries. This event was preceded by the outcome of the referendum of 16 March 2014 organized by the parliament of Crimea (Mucha W., 2014, p. 1)

Consequences for the situation of the world: Violation of the international law. Disturbance of the established world order and breach of principles of peaceful co-existence on the scale much larger than the region of dramatic events. Development and building of power of new empires in a specific part of the globe. The perspective of development of a dangerous situation in the direction of further aggressive moves, by the country annexing a foreign territory. Fears of countries neighboring with places of conflict, in terms of the upcoming future. Commencement of the weapon race and seeking alliances which may provide safety. Protests of international communities and attempts to counteract of eminent transnational organizations and institutions.

\subsection{Territories Which are of Strategic and Military Importance for a Specific Area of the World.}

Favorable location of so defined areas, in view of the performed by them actions in strategic and military sense, comes to the fore. The examples here are:

- Gibraltar - British overseas territory located on the Iberian Peninsula at the entrance to the Mediterranean Sea. - Guantanamo - American military base on Cuba for the entire region of the Caribbean.

- Kaliningrad Oblast for the whole zone of Baltic Sea.

- Diego Garcia is an island which belongs to the British Indian Ocean Territory, including Chagos Archipelago located in the middle part of the Indian Ocean. It is leased to the armed forces of the USA. It constitutes one of the most important American bases in the world.

Consequences for the situation of the world: Possession of military bases in critical regions of the world, provides the possibility to affect the course of events in accordance with interests of the countries which armies are stationed in them. The best example is Diego Garcia base which was used

in the time of two wars with Iraq (first and second war in the Persian Gulf) and in the time of American intervention in Afghanistan in 2001. Sometimes only the presence of a base of a specific country in a region may have impact on stability, or in the case of the need also on destabilization of the existing political situation.

\subsection{Regions Which Indicate Future Expansion Directions of Specific, Large Countries.}

The examples here may be:

-Annexation of Hawaii as the 50th and last so far state to the USA in 1959.

-New war in Europe, between the Ukraine and units belonging to self-proclaimed and pro-Russian: Luhansk Oblast and the Donetsk People's Republic.

-The mass settlement campaign for citizens of the People's Republic of China on large areas of Russian Siberia.

Consequences for the situation of the world: Transformation of Hawaii - the territory dependent on the USA into one of its states, symbolized extension of the zone of influence of this country to the whole area of the Pacific Ocean, South East Asia and Australia. Clashes of separatists from Luhansk Oblast and from the Donetsk People's Republic with the armed forces of the Ukraine, indicate clearly the range of the Russian zone of influence in the South East Europe and the direction of expansion of the largest country in the world. However, the most interesting example is the progressive colonization of the Russian Siberia by Chinese. In the context of the mass immigration of citizens of the Middle Kingdom one is to pay attention to the fact that these areas are relatively sparsely populated and wait to be settled. The greatest asset of Siberia from the perspective of China are immense natural resources of this land. (Rożek T., 2013, p. 6). Currently it is difficult to estimate the number of Chinese in the discussed area. The official data states that there are a few hundred thousands of specialists, workers, entrepreneurs and farmers. However, taking into consideration families accompanying the immigrants, the number may even amount to 2 million people. In extreme cases, the number of 5 million is stated. China demands that Moscow returns 1.5 million square kilometres of the Russian Far East. The country of tzars, under the colonial treaty signed in Beijing in 1860, took the area of that size from the Chinese Empire. One may be certain that the government of the People's Republic of China will claim these areas in upcoming 20 - 30 years ( Różycki T., 2014, p. 12). One may wonder why authorities in Kremlin do not oppose to the visible expansion of their neighbor. There is an explanation for that. Recently, economic contacts between both countries have been strengthened. Its visible effect is at least singing of "the contract of the century" for supplies of Russian gas to China. This fact makes it almost certain 
that there has been made a far-reaching agreement between two superpowers, regulating their mutual economic, political relations and also territorial matters. Weakening Russia may in this arrangement, for the price of large or even painful sacrifices, count on alliance with China giving Russia large benefits in future. Including even building of the new world order.

\subsection{Regions Located Within a Specific Country Which by the Use of Mechanisms and Democratic Methods Attempt to Become Independent and to Create Their Own Statehood According to the National Key.}

This situation applies to countries of developed structure of democratic political system of many years. In conditions of a certain weakness or crisis of the statehood, there may occur, in some areas, devolutionary tendencies aiming to secure larger autonomy by fighting and in the favorable system even their own statehood. The expression of such process is: -Separatist tendencies of French-speaking Quebec province in Canada which with different intensification can be observed from the half of the 20th century (Simard M., 2013, p. A3). In 1980 and subsequently in 1995, there took place referenda which outcome was however unfavorable for supporters of independence.

-The independence referendum in Scotland which conduct of was planned for 18 September 2014. Residents of Scotland, in a democratic manner, will decide this day on remaining or withdrawing from the United Kingdom.

-Idea of separating Catalonia from Spain. Despite the backlash of authorities in Madrid, prime minister of Catalonia, Artur Mas, declares that in October 2014 there will be organised a referendum on independence of this region (Stasiński M., 2014, p. 41).

Consequences for the situation of the world: Political and economic weakness of three out of twelve largest economies of the world. Potential decrease in the importance of each of them together and individually on the international arena. Loss of elements of important financial and economic associations within each country in the event of decrease in the previous territory. Possibility of losing a part of significant urban and industrial centers and their human capital by the Great Britain, Spain and Canada. Possible occurrence of domino effect, causing separation of other regions from weakened state units. Creation of a new political and economic order on European and North American continents. Formation of new countries aspiring to membership in international organisations such as: the European Union, NAFTA, UN, NATO, OECD, World Bank, European Bank for Reconstruction and Development etc.

\subsection{Regions Which in the Result of Natural Disasters, Unforeseen Incidents or an Outbreak of Dangerous Diseases Require International Aid.}

In the case of these territories, the aspect of humanitarian aid comes to the fore. Areas affected by natural disasters, incidents or epidemics need radical measures aiming to provide rescue to survivors and prevent danger of further unfavorable development of the situation. Examples:

- Nuclear power plant disaster in Chernobyl which resulted in radioactive contamination of the considerable area of Europe.

-Lethal epidemic of Ebola virus in Western Africa.

-Famine in Ethiopia in 1984 - 1985.

Consequences for the situation of the world: Such and similar events entail thousands of human victims. They are a tragedy especially for poor countries of Asia and Africa. However, rich countries such as Austria, Japan or the United Sates in the face of cataclysms ask for international aid. In the event of a disaster, the following organisations begin to act there: Red Cross and Red Crescent, World Health Organization, Food and Agriculture Organization of the United Nations, volunteers and institutions representing almost all countries of the world.

\subsection{Regions Which Status of Nationality Changes on the Basis of Voluntary Waiver of Rights to Possess Them by Previous Old Countries.}

The examples here may be:

-Sale of Alaska by the Russian Empire in favor of the United

States of North America in 1867.

-Handing over to the People's Republic of China of the territory of Hong Kong (Bard S., 2002, p. 5) by the Great Britain in 1997.

-Formal acquisition by the Chinese government from Portugal of sovereignty over the special administrative region - Macau in 1999. 
Consequences for the situation of the world: Such or similar events are symptoms of serious change in the balance of power on the global arena. In a symbolic manner, new and strong players get on the stage of politics and economy and previous, leading participants of the global show are put in the shade. The act of peaceful handing over of administration of a specific region to a new country frequently becomes a factor enabling a dynamic development of the said area. Position of a country expanding its territory is also being strengthened.

\subsection{Regions Which Expected in the Future Attractiveness Make Them Objects of a Political Game Already in Present Times.}

In connection with the progressive global warming during past several dozen years, the polar and subpolar areas located around the poles of our planet have become interesting in terms of exploitation. The additional encouragement intensifying interest of large number of countries is a potential possibility of occurrence of deposits of natural resources in the described areas. Examples:

- Territorial claims for fragments of Antarctica and islands bordering on it, before the Antarctic Treaty entering into force in 1961, have been submitted by seven countries. These are: Argentina, Australia, Chile, France, Norway, New Zealand and Great Britain. Renewal of this international agreement signed in Madrid freezes all territorial claims until 2041.

-Legal status of Arctic has not yet been regulated by any international agreement. Claims for its area are submitted by five countries. These are: Russia, USA, Canada, Denmark (by sovereignty over Greenland) and Norway.

-Maintaining of uninhabited territories of the Southern Atlantic, near the Southern Arctic Circle by: the Great Britain (South Georgia and South Sandwich) and Norway (Bouvet Islands).

Consequences for the situation of the world: Beside measurable profits such as the possibility to exploit in the upcoming future deposits of natural gas and petroleum, new possibilities of cheaper transport of resources and goods over longer distances are emerging. It relates to northern shipping lanes, such as: the Northern Sea Route along the shores of Russia and the Northwest Passage along the sea-coast of Canada and the USA. In both cases, the previous sea routes are being shortened by a few thousand kilometers. For example, a journey from Europe to the Far East or a journey from the East Coast of the USA to the West Coast may be significantly reduced in time - from a few to a dozen or so days (Kubiak K., 2014, pp.10 - 15).

\subsection{Regions Which are Remnants of Colonialist Past of Some Countries.}

The examples of such territories:

- overseas enclaves of Spain in the territory of Morocco: Ceuta and Melilla.

-Bermuda as the autonomous colony of the United Kingdom.

-French Polynesia.

Consequences for the situation of the world: Currently these territories are of minor importance in a global scale. However they remain a valued place for tourists from the whole world and the best card of a metropolis which they represent. They also promote in the surroundings a specific lifestyle and a civilization profile of specific cultural circles.

\section{Conclusion}

The presented classification of regions, based on the criterion of factors: their significance and influence on changes in the global scale, displays with itself a new value in reference to the previous comparisons and registers concentrating on numerical issues in statistical terms. It establishes 11 types of territories which ought to be taken into consideration in the context of the upcoming future. It enables to notice from another point of view the diversity that these regions represent. It gives a different, from the previous, possibility to take a look at the influence which events in these regions have on the world order. On the basis of several dozen selected examples, there has been demonstrated the increasing role of specific territories in the global politics and economy. In addition, this role is constantly expanding in view of the increasing economic potential, abundance of infrastructure and political significance of individual regions. Obviously not all the standing out areas are of crucial importance in the international scale. Only some of them leave their stamp on the course of events on our planet. However, their constantly increasing number is currently sufficient to 
change the nature of present relations. It is almost certain that the new order, which is as a matter of fact being created in front of our eyes, will begin on the level of regions and right from there it will spread on higher levels. Therefore it is so essential to look broadly at the issues relating to the described areas.

The prepared classification is not a closed list. In the author's intention, it should serve as the basis for further considerations on this topic. Its structure allows to make changes and complete it as needed. Taking into account these conditions, it may be useful as an efficient tool enabling to track and analyse changes occurring in the modern world.

\section{Bibliography}

- Bard S., (2002) Voices from the Past. Hong Kong 1842-1918. Hong Kong University Press, p. 5, Hongkong, China.

- $\quad$ Kerr George H., (1992), Formosa betrayed, second edition, Taiwan Publishing Co., Upland, USA.

- $\quad$ Kubiak K., (2014), Między nawigacją a polityką, Morze, Statki i Okręty, nr 3 - 4/2014 (143), pp.10 - 15, (03 -04/2014).

- Mucha W., (2014), Krym jednostronnie odrywa się od Ukrainy, Gazeta Polska, \#55 (756), p.1, (07/03/2014). CrossRef

- Przygoda M., (2013), Atrakcyjność inwestowania w regionach słabo rozwiniętych CrossRef

- Wydawnictwo Naukowe Wydziału Zarządzania Uniwersytetu Warszawskiego, Warszawa.

- Rożek T., Chińczycy na Syberii, Gość Niedzielny, p. 6, (GN 03/2013).

- $\quad$ Różycki T., Druga wojna krymska, Tygodnik Angora, nr 11 (1239), p.12, (16/03.2014).

- Simard M., (2013), Le PQ lance une campagne pour promouvoir l'indépendance, „Le Devoir”, p. A3, (22/04/2013).

- Stasiński M., (2014), Katalonia prze do konfliktu z Madrytem. Czy będzie referendum niepodległościowe i oderwanie od Hiszpanii ?, Gazeta Wyborcza (Stołeczna), nr 60, Świat, p. 41, (13/03/2014).

- 10.Wójcik L., (2014), Petrostan, Polityka, nr 28 (2966), pp. 38-40, (09.07-15.07.2014). 